\title{
Rituximab in the Treatment of Anti-Neutrophil Cytoplasm Antibody-Associated Vasculitis
}

\author{
Rachel B. Jones \\ Department of Renal Medicine, Addenbrooke's Hospital Cambridge, Cambridge, UK
}

\section{Key Words}

Anti-neutrophil cytoplasm antibody-associated vasculitis . Rituximab · Remission

\begin{abstract}
The introduction of cyclophosphamide and high-dose glucocorticoids for anti-neutrophil cytoplasm antibody (ANCA)associated vasculitis (AAV) has allowed a reduction in 1-year mortality from $80 \%$ to $10-20 \%$. AAV is now a chronic disease, and greater emphasis has turned to improving treatmentrelated toxicity, reducing relapses and providing alternative treatments for refractory disease. Rituximab, an anti-CD20 B cell-depleting therapy, has been used for over a decade in patients with AAV. Rituximab offers a significant advance in the treatment of these diseases. It has an established role for remission induction and is now being investigated as a remission maintenance agent. For remission induction, randomised trials have reported similar remission rates with rituximab and cyclophosphamide, and rituximab is now an approved alternative to cyclophosphamide in severe AAV. In clinical practice, rituximab is increasingly used for refractory and relapsing disease. Further remission induction data with rituximab for life-threatening renal and pulmonary disease may be provided by the ongoing PEXIVAS trial (NCT00987389). With standard therapies, 50\% of patients with newly diagnosed AAV relapse by 5 years. Relapses are
\end{abstract}

higher still in patients with known relapsing disease. For remission maintenance, treatment trials are comparing repeat rituximab dosing to azathioprine. The MAINRITSAN trial (NCT00748644) included mainly newly diagnosed AAV patients following cyclophosphamide induction therapy. The RITAZAREM trial (NCT01697267) is randomising patients with relapsing disease after rituximab induction therapy. Preliminary results with rituximab maintenance therapy are encouraging, although the optimal dosing regimen and duration has yet to be defined. Other areas for further investigation include remission maintenance therapy requirement after rituximab induction in newly diagnosed AAV, and the role of rituximab in eosinophilic granulomatosis with polyangiitis where no randomised data exists.

(c) 2014 S. Karger AG, Basel

\section{Introduction}

The anti-neutrophil cytoplasm antibody (ANCA)-associated vasculitides are autoimmune diseases characterised by a necrotising small vessel vasculitis and ANCA

Biologic Treatment in Glomerular Disease

D. Jayne, Cambridge

V. Tesar, Prague

\section{KARGER}

E-Mail karger@karger.com

www.karger.com/nec
(C) 2014 S. Karger AG, Basel

1660-2110/14/1284-0243\$39.50/0
Rachel B. Jones

Department of Renal Medicine

Addenbrooke's Hospital Cambridge

Cambridge (UK)

E-Mail rbj23@cam.ac.uk 
targeting either proteinase 3 or myeloperoxidase. ANCAassociated-vasculitis (AAV) includes three diseases: granulomatosis with polyangiitis (GPA; previously Wegener's granulomatosis), microscopic polyangiitis (MPA) and eosinophilic GPA (EGPA, previously Churg-Strauss syndrome) [1]. Both GPA and MPA are associated with pauci-immune necrotising glomerulonephritis as the most common severe manifestation, which untreated progresses to end-stage renal disease. Due to similarities in disease manifestations and early treatment responses, GPA and MPA are frequently grouped together in therapeutic trials. The key differences between these two diseases are the presence of respiratory tract granuloma in GPA and the association of GPA with proteinase 3-ANCA and MPA with predominantly myeloperoxidase-ANCA (proteinase 3-ANCA being associated with greater relapse risk) [2]. EGPA is usually considered separately in treatment trials. EGPA is differentiated by a peripheral eosinophilia and asthma [1], and compared to GPA and MPA, EGPA has lower rates of ANCA positivity and renal vasculitis. Consequently, evidence for new therapies in AAV tends to rely mainly on experience in GPA and MPA patients.

Since the introduction of cyclophosphamide and high-dose glucocorticoids in the 1970s, AAV has transformed from a disease with $80 \%$ mortality [3], into a chronic relapsing and remitting disease. Current outcomes at 5 years are $25 \%$ mortality and a $50 \%$ relapse rate [2]. Treatment strategies have evolved to 3-6 months of remission induction therapy, followed by $12-24$ months of remission maintenance therapy, following which treatment withdrawal is considered [4]. In severe disease with major organ involvement, cyclophosphamide with highdose glucocorticoids is standard induction therapy. Azathioprine and methotrexate, with low-dose glucocorticoids, are standard remission maintenance agents [5]. Plasma exchange is an adjunctive therapy for remission induction in patients with poor renal function (creatinine $>500 \mu \mathrm{mol} / \mathrm{l}$ ) [6]. Newer therapies are being investigated in order to further improve disease-related outcomes, e.g. reducing refractory disease, relapse and chronic organ damage. Another important expectation for new treatments is reduced toxicity compared to cyclophosphamide and high-dose glucocorticoids, particularly lower infection, malignancy and infertility risks. Rituximab is a potential alternative to cyclophosphamide and offers a significant advance in the treatment of AAV. This article reviews the current evidence for rituximab as a remission induction and remission maintenance therapy in AAV.

\section{Rationale for a B Cell-Depleting Therapy in AAV}

Rituximab is a chimeric monoclonal antibody that binds to CD20, a calcium ion channel, expressed on most $\mathrm{B}$ cells, except plasma cells [7]. Rituximab results in rapid $\mathrm{B}$ cell depletion using antibody-dependent cell-mediated cytotoxicity, complement-mediated cytotoxicity and apoptotic mechanisms [8]. It was originally approved to treat B cell lymphoma in 1995. The benefit of rituximab in antibody-associated autoimmune diseases, particularly rheumatoid arthritis [9], led to the evaluation of rituximab in AAV.

There is a strong rationale for the use of $\mathrm{B}$ cell-targeted therapies in AAV: B cell activation occurs in active AAV $[10,11]$, ANCA are produced by $B$ cells which are strongly implicated in disease pathogenesis $[12,13]$, autoreactive B cells are present in granulomatous lesions in GPA $[14,15]$, and cyclophosphamide suppresses B cell activation and proliferation [16] and is efficacious treatment for AAV. Rituximab appears effective in both ANCA-positive and ANCA-negative AAV [17]. Rituximab likely works through additional mechanisms beyond just the depletion of precursors to ANCA-producing cells.

\section{Remission Induction Therapy for Refractory AAV}

The initial experience with rituximab in AAV was in patients with either cyclophosphamide refractory disease or relapsing disease. The first case report was published in 2001 [18]. Subsequent pilot trials [19, 20] and retrospective case series described high remission rates with rituximab (typically $80-100 \%$; e.g. [21-26]). More than 250 cases have now been reported in the literature. One early report described failure to induce remission in patients with severe granulomatous manifestations [27]. However, this study reported short-term outcomes only. Studies with longer follow-up have found rituximab to be effective for both granulomatous and vasculitic disease [17]. Severe granulomatous manifestations such as orbital or meningeal disease typically show slower and less complete response to a first rituximab course. This may be due to incomplete B cell depletion within granulomatous lesions. Subsequent repeat rituximab dosing appears to facilitate full remission in such patients [28].

Initial reports used one of two different rituximab dosing regimens: either four doses of $375 \mathrm{mg} / \mathrm{m}^{2}$ body surface area administered once a week for 4 weeks (the original lymphoma dosing regimen) or two doses of $1,000 \mathrm{mg}$ administered 2 weeks apart (the rheumatoid arthritis reg- 
imen). Both regimens induce remission in AAV and prolonged B cell depletion lasting 6-12 months on average, with most patients achieving peripheral B cell return by 24 months $[17,29]$. In relapsing and refractory AAV, relapses are common after a single rituximab course, with rates of 57 and $48 \%$ within 24 months reported in two large cohorts $[17,30]$. However, repeat dosing with rituximab induces further remissions. Although rituximab has potential to be immunogenic, this does not appear to be clinically relevant in AAV with the doses of rituximab used. Patients can relapse multiple times following rituximab, and multiple re-treatments with rituximab continue to induce further remissions.

Most case series have focused on patients with GPA where relapsing disease is common. In EGPA, limited data suggests that successful remissions can be achieved with rituximab in both ANCA-positive and ANCA-negative disease [31, 32]. Overall, non-randomised data suggests that rituximab induces remissions in most treatment-resistant AAV patients, with the greatest evidence in GPA. Rituximab is now increasingly used to treat refractory and relapsing AAV.

\section{Treatment Trials with Rituximab for Remission Induction in AAV}

Following uncontrolled reports of efficacy with rituximab in refractory AAV, two randomised trials have compared rituximab to cyclophosphamide for remission induction in severe GPA and MPA [33, 34]. The design and major outcomes of both studies are summarised in table 1. Key differences in the RAVE trial were the inclusion of patients with relapsing as well as newly diagnosed $\mathrm{AAV}$, exclusion of patients with creatinine greater than $354 \mu \mathrm{mol} / \mathrm{l}$ and complete withdrawal of glucocorticoids by 6 months [33]. In contrast, the RITUXVAS trial recruited only patients with newly diagnosed renal AAV (including those with dialysis dependence), used two intravenous doses of cyclophosphamide in the rituximab group and continued low-dose glucocorticoids beyond 6 months [34]. Both trials reported similar remission rates between the cyclophosphamide and rituximab groups. In the RAVE trial, rituximab was associated with superior remission rates in the subgroup of patients with relapsing disease. Following the RAVE trial, rituximab $375 \mathrm{mg} / \mathrm{m}^{2}$ administered once a week for 4 weeks gained regulatory approval for remission induction in severe AAV.

Dialysis-dependent patients were excluded from the RAVE trial and were few in number in the RITUXVAS study. Further investigation of rituximab in this important subgroup is therefore required. The ongoing PEXIVAS plasma exchange trial (NCT00987389) is recruiting 500 patients, including those with dialysis dependence. PEXIVAS permits the use of either cyclophosphamide or rituximab for remission induction, so it may expand knowledge of rituximab's efficacy in this subgroup.

At the final follow-up in the RAVE and RITUXVAS trials, relapse rates were similar between groups $[35,36]$. Neither trial used remission maintenance therapy in the rituximab group; both trials used azathioprine maintenance therapy in the cyclophosphamide group. Relapses in rituximab patients occurred after B cell return in all RITUXVAS patients and most RAVE trial patients. Vigilance for relapse is recommended, following B cell return in patients not receiving remission maintenance therapy after a rituximab induction course [36]. It has yet to be determined whether relapses after rituximab in newly diagnosed AAV can be reduced by remission maintenance agents.

\section{Rituximab as Remission Maintenance Therapy in AAV}

In relapsing and refractory AAV, relapse rates are high after a single rituximab induction course. The average time to relapse is 13 months [17,30]. Relapses usually, but not always, occur following peripheral $\mathrm{B}$ cell return. The timing of relapse in relation to $\mathrm{B}$ cell return is imprecise. Some patients relapse at the time of B cell return, some relapse many months later and a minority appear not to relapse at all. This lack of precision likely reflects the inexact relationship between peripheral $\mathrm{B}$ cells and tissue $\mathrm{B}$ cell activity. B cells have been identified within inflamed tissues in patients relapsing in the absence of peripheral B cells [37].

Following rituximab for relapsing AAV, most investigators have withdrawn concomitant immunosuppressants to reduce toxicity $[17,28,29]$. However, continued use of oral immunosuppressants may help reduce relapses [30]. An alternative remission maintenance strategy, adopted by several investigators, is repeat rituximab dosing during remission. Studies using rituximab as maintenance therapy are summarised in table 2 . No consensus on the optimal maintenance strategy has been achieved. Options include the use of B cells with ANCA to determine the timing of rituximab treatment. Success with this approach was reported by Cartin-Ceba et al. [32], who observed no relapses in patients who met the re-treatment criteria; however, 
Table 1. Comparison of the RAVE $[33,35]$ and the RITUXVAS $[34,36]$ AAV remission induction trials

RAVE

Randomised, double blinded, non-inferiority, Randomised, open label, superiority, 18 months follow-up

Oral CYC for 3-6 months

High-dose glucocorticoids, tapered then withdrawn at 6 months

RTX $375 \mathrm{mg} / \mathrm{m}^{2} \times 4$

High-dose glucocorticoids, tapered then

withdrawn at 6 months

\section{RITUXVAS}

24 months follow-up

IV CYC for 3-6 months prednisolone at 6 months

RTX $375 \mathrm{mg} / \mathrm{m}^{2} \times 4$

2 doses IV CYC
RTX group induction regimen

Control group induction regimen

Oral azathioprine
High-dose glucocorticoids, tapered to $5 \mathrm{mg}$

High-dose glucocorticoids, tapered to $5 \mathrm{mg}$ prednisolone at 6 months

\begin{tabular}{lll}
\hline Control group maintenance regimen & Oral azathioprine & $\begin{array}{l}\text { Oral azathioprine } \\
\text { Low-dose glucocorticoids }\end{array}$ \\
\hline RTX group maintenance regimen & None & Low-dose glucocorticoids \\
\hline Plasma exchange usage & Not permitted & Optional use permitted \\
\hline Primary remission endpoint & $\begin{array}{l}\text { Remission at } 6 \text { months (with adherence to } \\
\text { glucocorticoid withdrawal) }\end{array}$ & $\begin{array}{l}\text { Remission sustained for } 6 \text { months by } \\
12 \text { months }\end{array}$ \\
\hline Population characteristics & $197(99$ RTX, 98 CYC) & 44 (33 RTX, 11 CYC) \\
Patients & GPA 148 (75\%) & GPA 22 (50\%) \\
\hline AAV subtype & MPA $48(25 \%)$ & MPA 16 (36\%) \\
& & Renal limited vasculitis 6 (14\%) \\
\hline New/relapsing disease & New disease 96 (48\%) & New disease $44(100 \%)$ \\
\hline Renal vasculitis & Relapsing disease $101(52 \%)$ & \\
\hline Dialysis requirement at entry & $130(66 \%)$ & $44(100 \%)$ \\
\hline ANCA positive at entry & Excluded if creatinine $>354 \mu$ mol/1 & No renal exclusion criteria \\
\hline
\end{tabular}

\section{Key outcomes}

Primary remission endpoint

63 (64\%) RTX, 52 (53\%) CYC

25 (76\%) RTX, 9 (82\%) CYC

Remission in patients with relapsing disease: 34 (67\%) RTX, 21 (42\%) CYC

\begin{tabular}{ll}
\hline Relapses at trial end & Severe relapses \\
& $27(27 \%)$ RTX, 24 (24\%) CYC \\
& Limited relapses \\
& $20(20 \%)$ RTX, $21(21 \%)$ CYC
\end{tabular}

\begin{tabular}{lll}
\hline Infections at trial end & Severe infections & Serious infections \\
& $22(12 \%)$ RTX, 11 (11\%) CYC & $11(33 \%)$ RTX, 2 (18\%) CYC \\
\hline Mortality at trial end & $2(2 \%)$ RTX, 2 (2\%) CYC & $6(18 \%)$ RTX, 3 (27\%) CYC
\end{tabular}

Results are expressed as numbers and percentages. RTX = Rituximab; CYC = cyclophosphamide. 
Table 2. Rituximab remission maintenance studies in AAV

\begin{tabular}{|c|c|c|c|c|}
\hline Study author & Study design & Patient number & Rituximab maintenance protocol & Proportion with relapse \\
\hline $\begin{array}{l}\text { Rhee et al. } \\
\text { [38] }\end{array}$ & $\begin{array}{l}\text { retrospective } \\
\text { case series }\end{array}$ & 39 & $1,000 \mathrm{mg}$ every 4 months & $7.6 \%$ after 18 months (mean) \\
\hline $\begin{array}{l}\text { Smith et al. } \\
{[28]}\end{array}$ & $\begin{array}{l}\text { retrospective } \\
\text { case series }\end{array}$ & 64 (group B: 45; group C: 19) & $\begin{array}{l}1,000 \mathrm{mg} \text { every } 6 \text { months for } \\
2 \text { years }\end{array}$ & $\begin{array}{l}12 \% \text { group B } \\
11 \% \text { group C }\end{array}$ \\
\hline $\begin{array}{l}\text { Cartin-Ceba } \\
\text { et al. [29] }\end{array}$ & $\begin{array}{l}\text { retrospective } \\
\text { case series }\end{array}$ & $\begin{array}{l}53 \text { considered for retreatment } \\
\text { (number retreated not } \\
\text { specified) }\end{array}$ & $\begin{array}{l}4 \text { doses of } 375 \mathrm{mg} / \mathrm{m}^{2}(90 \%) \\
2 \text { doses of } 1,000 \mathrm{mg}(10 \%) \\
\text { based on B cell and ANCA criteria }\end{array}$ & $\begin{array}{l}0 \% \text { in patients re-treated at } \\
4.4 \text { years (median) (NB } 32 \\
\text { relapses occurred in patients } \\
\text { not re-treated) }\end{array}$ \\
\hline $\begin{array}{l}\text { Roubaud- } \\
\text { Baudron et al. } \\
{[39]}\end{array}$ & $\begin{array}{l}\text { retrospective } \\
\text { case series }\end{array}$ & 28 & $\begin{array}{l}375 \mathrm{mg} / \mathrm{m}^{2} \text { every } 6 \text { months, } \mathrm{n}=14 \\
1,000 \mathrm{mg} \text { every } 6 \text { months, } \mathrm{n}=4 \\
1,000 \mathrm{mg} \text { every } 12 \text { months, } \mathrm{n}=3 \\
\text { Other regimens, } \mathrm{n}=7\end{array}$ & $7 \%$ at 38 months (median) \\
\hline
\end{tabular}

relapses were observed in patients who did not undergo re-treatment. Other investigators have found B cells and ANCA insufficiently reliable as relapse predictors, perhaps partly due to the treatment of more ANCA-negative patients [17]. An alternative remission maintenance approach is re-dosing with rituximab at fixed time intervals. Both 4-month [38] and 6-month [28] dosing intervals have been used [39], with low relapse rates observed. Consequently, rituximab maintenance strategies are now being evaluated in randomised trials. For relapsing AAV, the RITAZAREM trial is comparing $1,000 \mathrm{mg}$ rituximab every 4 months to azathioprine, after rituximab induction therapy (1,000 $\mathrm{mg} \times 2$; NCT01697267). In newly diagnosed $\mathrm{AAV}$, there is scope to improve the $50 \% 5$-year relapse rate observed following standard cyclophosphamide induction and azathioprine maintenance regimens. The role of rituximab maintenance therapy after cyclophosphamide induction in newly diagnosed AAV has been evaluated by the MAINRITSAN trial (NCT00748644). $500 \mathrm{mg}$ of rituximab every 6 months was compared to azathioprine. Results found a lower relapse rate in rituximab patients: $5 \%$ versus $29 \%$ at 2 years [40]. A further trial has been proposed to compare two rituximab $500 \mathrm{mg}$ dosing strategies: either dosing every 6 months or re-treatment based on B cell and ANCA return (MAINRITSAN 2; NCT01731561).

The optimal duration of rituximab maintenance therapy is unknown. Uncontrolled studies and randomised trials have used a 2-year rituximab re-dosing regimen, followed by rituximab withdrawal and observation for re- lapse [28, 40, NCT01697267]. Initial data suggests that time to relapse is longer after a 2-year rituximab course than a single treatment course [28]. Withdrawal of rituximab at 2 years may therefore prove to be a reasonable approach. However, further outcome data is awaited to substantiate this.

\section{Safety of Rituximab in AAV}

Overall, rituximab appears to be well tolerated in AAV. Neither the RAVE nor the RITUXVAS trial raised specific safety concerns with rituximab, although patient numbers were low. Further rituximab safety data is drawn from uncontrolled AAV cohorts and studies in rheumatoid arthritis and oncology indications.

In AAV, infusion reactions with rituximab are usually mild. However, potentially fatal infusion reactions can occur, but are very rare. Therefore, premedication with paracetamol, antihistamine and $100 \mathrm{mg}$ methylprednisolone is recommended prior to each infusion [41].

Infection risk with rituximab has not been fully quantified in AAV. Notably, neither the RAVE nor the RITUXVAS trial found infections to be lower in the rituximab versus cyclophosphamide groups. Rituximab depletes the precursors to antibody-producing cells and is associated with significant falls in IgM within 3-6 months of use [19]. In relapsing patients, IgG levels are often low before rituximab, reflecting prior immunosuppression 
exposure [42]. Following rituximab, transient falls in IgG are frequent and a minority develop sustained severe hypogammaglobulinaemia [42, 43]. Prior cyclophosphamide exposure and ongoing glucocorticoids may contribute to hypogammaglobulinaemia following rituximab. Monitoring IgG can be helpful to differentiate transient from sustained hypogammaglobulinaemia, particularly in patients with recurrent infections. Moderate or severe hypogammaglobulinaemia complicated by recurrent infection is an indicator to consider rituximab withdrawal and IgG replacement therapy.

Other potentially fatal infective complications include progressive multifocal leucoencephalopathy following JC virus reactivation, and fulminant liver failure due to hepatitis B reactivation. Progressive multifocal leucoencephalopathy in rituximab-treated patients is very rare, but fatal, so physicians and patients should be aware of the risk. Patients should be screened for hepatitis B prior to rituximab to exclude active infection or prior exposure. In patients with prior exposure, lamivudine prophylaxis is recommended. Rituximab should be avoided in patients with active hepatitis B. Another infective risk with rituximab is late-onset neutropenia, which is identified in approximately $5 \%$ of patients [44], although the true incidence is unknown. Neutropenia is usually transient. If required, granulocyte colony-stimulating factor can expedite recovery of granulocyte counts.

In patients at risk of malignancy, rituximab may be considered preferable to cyclophosphamide, which has well-established malignancy risks. In AAV, long-term malignancy data with rituximab is not available. In rheu- matoid arthritis, malignancies are not increased by the addition of rituximab to methotrexate [45]. In oncology, however, more solid organ malignancies were reported during 5-10 years of follow-up after rituximab with chemotherapy compared to chemotherapy alone [46].

\section{Conclusions}

Rituximab has been used to treat AAV for more than 10 years. Randomised trials investigating rituximab for remission induction have been performed. Rituximab is now an approved alternative to cyclophosphamide for remission induction, and is increasingly used to treat patients with relapsing or refractory disease. Relapse rates are high after rituximab in relapsing AAV. However, repeat dosing is effective and consequently rituximab maintenance strategies have evolved. Remission maintenance trials comparing rituximab to azathioprine are underway, and provisional results are promising. Areas for further investigation include remission maintenance therapy requirements in newly diagnosed patients treated with rituximab induction therapy, optimal dosing and duration of rituximab for remission maintenance, and the efficacy of rituximab for EGPA.

\section{Disclosure Statement}

Dr. Jones undertook a part-time academic secondment to GlaxoSmithKline from 2011 to 2013.

\section{References}

$>1$ Jennette JC, Falk RJ, Bacon PA, Basu N, Cid $\mathrm{MC}$, Ferrario F, et al: 2012 revised International Chapel Hill Consensus Conference Nomenclature of Vasculitides. Arthritis Rheum 2013;65:1-11.

-2 Walsh M, Flossmann O, Berden A, Westman K, Höglund P, Stegeman C, Jayne D; European Vasculitis Study Group: Risk factors for relapse of anti-neutrophil cytoplasmic antibody-associated vasculitis. Arthritis Rheum 2012;64:542-548.

-3 Walton EW: Giant-cell granuloma of the respiratory tract (Wegener's granulomatosis). Br Med J 1958;34:265-270.

-4 Mukhtyar C, Guillevin L, Cid MC, Dasgupta B, de Groot K, Gross W, Hauser T, Hellmich B, Jayne D, Kallenberg CG, Merkel PA, Raspe H, Salvarani C, Scott DG, Stegeman C, Watts R, Westman K, Witter J, Yazici H, Luqmani R; European Vasculitis Study Group: EULAR recommendations for the management of primary small and medium vessel vasculitis. Ann Rheum Dis 2009;68:310-317.

-5 Jayne D, Rasmussen N, Andrassy K, Bacon P, Tervaert JW, Dadoniené J, Ekstrand A, Gaskin G, Gregorini G, de Groot K, Gross W, Hagen EC, Mirapeix E, Pettersson E, Siegert C, Sinico A, Tesar V, Westman K, Pusey C; European Vasculitis Study Group: A randomized trial of maintenance therapy for vasculitis associated with antineutrophil cytoplasmic autoantibodies. N Engl J Med 2003;349:3644.

-6 Jayne DR, Gaskin G, Rasmussen N, Abramowicz D, Ferrario F, Guillevin L, Mirapeix E, Savage CO, Sinico RA, Stegeman CA, Westman KW, van der Woude FJ, de Lind van Wijngaarden RA, Pusey CD; European Vasculitis Study Group: Randomized trial of plasma exchange or high-dosage methylpredniso- lone as adjunctive therapy for severe renal vasculitis. J Am Soc Nephrol 2007;18:21802188.

$\checkmark 7$ Tedder TF, Engel P: CD20: a regulator of cellcycle progression of B lymphocytes. Immunol Today 1994; 15:450-454.

$>8$ Reff ME, Carner K, Chambers KS, Chinn PC, Leonard JE, Raab R, Newman RA, Hanna N, Anderson DR: Depletion of B cells in vivo by a chimeric mouse human monoclonal antibody to CD20. Blood 1994;83:435-445.

$\checkmark 9$ Edwards JC, Cambridge G: Sustained improvement in rheumatoid arthritis following a protocol designed to deplete $\mathrm{B}$ lymphocytes. Rheumatology (Oxford) 2001;40:205211.

10 Popa ER, Stegeman C, Bos NA, Kallenberg CG, Tervaert JW: Differential B- and T-cell activation in Wegener's granulomatosis. J Allergy Clin Immunol 1999;103:885-894. 
-11 Holden NJ, Williams JM, Morgan MD, Challa A, Gordon J, Pepper RJ, Salama AD, Harper L, Savage CO: ANCA-stimulated neutrophils release BLyS and promote $B$ cell survival: a clinically relevant cellular process. Ann Rheum Dis 2011;70:2229-2233.

-12 Xiao H, Heeringa P, Hu P, Liu Z, Zhao M, Aratani Y, Maeda N, Falk RJ, Jennette JC: Antineutrophil cytoplasmic autoantibodies specific for myeloperoxidase cause glomerulonephritis and vasculitis in mice. J Clin Invest 2002;110:955-963.

13 Little MA, Al-Ani B, Ren S, Al-Nuaimi H, Leite M Jr, Alpers CE, Savage CO, Duffield JS: Anti-proteinase 3 anti-neutrophil cytoplasm autoantibodies recapitulate systemic vasculitis in mice with a humanized immune system. PLoS One 2012;7:e28626.

14 Voswinkel J, Müller A, Lamprecht P: Is PR3ANCA formation initiated in Wegener's granulomatosis lesions? Granulomas as potential lymphoid tissue maintaining autoantibody production. Ann NY Acad Sci 2005; 1051:12-19.

-15 Voswinkel J, Müller A, Kraemer JA, Lamprecht P, Herlyn K, Holl-Ulrich K, Feller AC, Pi$\operatorname{tann}$ S, Gause A, Gross WL: B lymphocyte maturation in Wegener's granulomatosis: a comparative analysis of $\mathrm{VH}$ genes from endonasal lesions. Ann Rheum Dis 2006;65:859-864.

$\checkmark 16$ Cupps TR, Edgar LC, Fauci AS: Suppression of human B lymphocyte function by cyclophosphamide. J Immunol 1982;128:24532457.

$\checkmark 17$ Jones RB, Ferraro AJ, Chaudhry AN, Brogan $\mathrm{P}$, Salama AD, Smith KG, Savage CO, Jayne DR: A multicenter survey of rituximab therapy for refractory antineutrophil cytoplasmic antibody-associated vasculitis. Arthritis Rheum 2009;60:2156-2168.

-18 Specks U, Fervenza FC, McDonald TJ, Hogan MC: Response of Wegener's granulomatosis to anti-CD20 chimeric monoclonal antibody therapy. Arthritis Rheum 2001;44:28362840.

19 Smith KG, Jones RB, Burns SM, Jayne DRW: Long-term comparison of rituximab treatment for refractory systemic lupus erythematosus and vasculitis. Remission, relapse, and re-treatment. Arthritis Rheum 2006;54:29702982.

-20 Keogh KA, Ytterberg SR, Fervenza FC, Carlson KA, Schroeder DR, Specks U: Rituximab for refractory Wegener's granulomatosis: report of a prospective, open-label pilot trial. Am J Respir Crit Care Med 2006;173:180-187.

$\checkmark 21$ Eriksson P: Nine patients with anti-neutrophil cytoplasmic antibody-positive vasculitis successfully treated with rituximab. J Intern Med 2005;257:540-548.

22 Keogh KA, Wylam ME, Stone JH, Specks U: Induction of remission by B lymphocyte depletion in eleven patients with refractory antineutrophil cytoplasmic antibody-associated vasculitis. Arthritis Rheum 2005;52:262-268.

-23 Stasi R, Stipa E, Del Poeta G, Amadori S, Newland AC, Provan D: Long-term observations of patients with anti-neutrophil cytoplasmic antibody-associated vasculitis treated with rituximab. Rheumatology (Oxford) 2006;45: 1432-1436.

24 Lovric S, Erdbruegger U, Kümpers P, Woywodt A, Koenecke C, Wedemeyer H, Haller $\mathrm{H}$, Haubitz M: Rituximab as rescue therapy in anti-neutrophil cytoplasmic antibody-associated vasculitis: single centre experience with 15 patients. Nephrol Dial Transplant 2009;24; 179-185.

25 Seo P, Specks U, Keogh KA: Efficacy of rituximab in limited Wegener's granulomatosis with refractory granulomatous manifestations. J Rheumatol 2008;35:2017-2023.

26 Sánchez-Cano D, Callejas-Rubio J, OrtegoCenteno N: Effect of rituximab on refractory Wegener granulomatosis with predominant granulomatous disease. J Clin Rheumatol 2008;14:92-93.

27 Aries PM, Hellmich B, Voswinkel J, Both M, Nolle B, Holl-Ulrich K, Lamprecht P, Gross WL: Lack of efficacy of rituximab in Wegener's granulomatosis with refractory granulomatous manifestations. Ann Rheum Dis 2006;65:853-858.

28 Smith RM, Jones RB, Guerry MJ, Laurino S, Catapano F, Chaudhry A, Smith KG, Jayne DR: Rituximab for remission maintenance in relapsing ANCA-associated vasculitis. Arthritis Rheum 2012;64:3760-3769.

29 Cartin-Ceba R, Golbin JM, Keogh KA, Peikert T, Sánchez-Menéndez M, Ytterberg SR, Fervenza FC, Specks U: Rituximab for remission induction and maintenance in refractory granulomatosis with polyangiitis (Wegener's): ten-year experience at a single center. Arthritis Rheum 2012;64:3770-3778.

-30 Azar L, Springer J, Langford CA, Hoffman GS: Rituximab with or without a conventional maintenance agent in relapsing granulomatosis with polyangiitis: a retrospective singlecenter study. Arthritis Rheumatol 2014;66: 2862-2870.

-31 Thiel J, Hässler F, Salzer U, Voll RE, Venhoff $\mathrm{N}$ : Rituximab in the treatment of refractory or relapsing eosinophilic granulomatosis with polyangiitis (Churg-Strauss syndrome). Arthritis Res Ther 2013;15:R133.

32 Cartin-Ceba R, Keogh KA, Specks U, Sethi S, Fervenza FC: Rituximab for the treatment of Churg-Strauss syndrome with renal involvement. Nephrol Dial Transplant 2011;26: 2865-2871.

33 Stone JH, Merkel PA, Spiera R, Seo P, Langford CA, Hoffman GS, et al: Rituximab versus cyclophosphamide for ANCA-associated vasculitis. N Engl J Med 2010;363:221-232.

34 Jones RB, Tervaert JW, Hauser T, Luqmani R, Morgan MD, Peh CA, Savage CO, Segelmark M, Tesar V, van Paassen P, Walsh D, Walsh M, Westman K, Jayne DR; European Vasculitis Study Group: Rituximab versus cyclophosphamide in ANCA-associated renal vasculitis. N Engl J Med 2010;363:211-220.

- 35 Specks U, Merkel PA, Seo P, Spiera R, Langford CA, Hoffman GS, et al: Efficacy of remis- sion-induction regimens for ANCA-associated vasculitis. N Engl J Med 2013;369:417-427.

36 Jones RB, Walsh M, Jayne D: Two-year follow-up results from a randomized trial of rituximab versus cyclophosphamide for ANCA-associated renalvasculitis:RITUXVAS. Clin Exp Immunol 2011;164:57.

- 37 Ferraro AJ, Smith SW, Neil D, Savage COS Relapsed Wegener's granulomatosis after rituximab therapy $-\mathrm{B}$ cells are present in new pathological lesions despite persistent 'depletion' of peripheral blood. Nephrol Dial Transplant 2008;23:3030-3032.

38 Rhee EP, Laliberte KA, Niles JL: Rituximab as maintenance therapy for anti-neutrophil cytoplasmic antibody-associated vasculitis. Clin J Am Soc Nephrol 2010;5:1394-1400.

39 Roubaud-Baudron C, Pagnoux C, MeauxRuault N, Grasland A, Zoulim A, Le Guen J, Prud'homme A, Bienvenu B, de Menthon M, Camps S, LE Guern V, Aouba A, Cohen P, Mouthon L, Guillevin L; French Vasculitis Study Group: Rituximab maintenance therapy for granulomatosis with polyangiitis and microscopic polyangiitis. J Rheumatol 2012; 39:125-130.

40 Guillevin L, Pagnoux C, Karras A, Khouatra C, Aumaître O, Cohen P, Maurier F, Decaux O, Ninet J, Gobert P, Quémeneur T, BlanchardDelaunay C, Godmer P, Puéchal X, Carron PL, Hatron PY, Limal N, Hamidou M, Ducret M, Daugas E, Papo T, Bonnotte B, Mahr A, Ravaud P, Mouthon L; the French Vasculitis Study Group: Rituximab versus Azathioprine for Maintenance in ANCA-Associated Vasculitis. N Engl J Med 2014;371:1771-1780.

41 EMA summary of product chracteristics. http://www.ema.europa.eu/docs/en_GB/ document_library/EPAR_-_Product_Inform ation/human/000165/WC500025821.pdf.

42 Marco H, Smith RM, Jones RB, Guerry MJ Catapano F, Burns S, et al: The effect of rituximab therapy on immunoglobulin levels in patients with multisystem autoimmune disease. BMC Musculoskelet Disord 2014; 15:178.

43 Venhoff N, Effelsberg N, Salzer U, Warnatz K, Peter $\mathrm{H}$, Lebrecht $\mathrm{D}$, et al: Impact of rituximab on immunoglobulin concentrations and $B$ cell numbers after cyclophosphamide treatment in patients with ANCA-associated vasculitides. PloS One 2012;7:e37626.

44 Tesfa D, Palmblad J: Late-onset neutropenia following rituximab therapy: incidence, clinical features and possible mechanisms. Expert Rev Hematol 2011;4:619-625.

45 van Vollenhoven RF, Emery P, Bingham CO $3 \mathrm{rd}$, et al: Long-term safety of rituximab in rheumatoid arthritis: 9.5-year follow-up of the global clinical trial programme with a focus on adverse events of interest in RA patients. Ann Rheum Dis 2013;72:1496-1502.

46 Tarella C, Passera R, Magni M, et al: Risk factors for the development of secondary malignancy after high-dose chemotherapy and autograft, with or without rituximab: a 20-year retrospective follow-up study in patients with lymphoma. J Clin Oncol 2011;29:814-824. 